\title{
Implementasi Bauran Promosi dalam Upaya Meningkatkan Pendapatan Perusahaan (Studi Kasus Pada CV. Tunas Abadi Kota Malang)
}

\author{
Dedy Musthafa \\ Manajemen, Fakultas Ekonomi \\ Universitas Islam Negeri (UIN) Maulana Malik Ibrahim Malang \\ dedy.musthafa@gmail.com
}

\begin{abstract}
CV. Tunas Abadi is one of the companies that consistently uses traditional promotional tools by utilizing sales-promotors to offer company products directly. The purposes of this study are to reveal the implementation and implications of the implementation of the promotional mix in increasing company's revenue on CV. Tunas Abadi Malang City. This study used a descriptive qualitative approach that aims to find a Comprehensive description of the implementation of the promotional mix on CV Tunas Abadi Malang City. The subjects of this study were 4 informants. Data analysis aims to simplify the results of data processing. The data obtained through interview, observation, and study of literature techniques. While analyzing data through four stages, were: reduction, display of data, making conclusions, and triangulation. From the results of the study showed that by CV. Tunas Abadi Malang City applies a promotional mix in the form of advertising, personal selling, public relations, sales promotion and direct marketing. The implications of the implementation of the promotional mix effect to Company though not all combinations have a big impact on the company.
\end{abstract}

Key Words: Promotional Mix, Company's Reveanue

\section{Abstrak}

CV. Tunas Abadi merupakan salah satu perusahaan yang konsisten menggunakan alat promosi yang bersifat tradisional dengan memanfaatkan tenaga penjualan untuk menawarkan produk perusahaan secara langsung. Tujuan penelitian ini adalah mengungkapkan implementasi dan implikasi dari Implementasi bauran promosi dalam upaya meningkatkan pendapatan perusahaan di CV. Tunas Abadi Kota Malang. Penelitian ini menggunakan pendekatan kualitatif deskriptif yang bertujuan untuk mencari suatu uraian yang menyeluruh dan teliti terhadap implementasi bauran promosi pada CV Tunas Abadi Malang. Subjek penelitian ini terdapat 4 informan. Analisis data bertujuan untuk menyederhanakan hasil olahan data. Adapun data diperolah melalui teknik wawancara, observasi, dan studi kepustakaan. Sedangkan analisa data melalui empat tahap, yaitu : reduksi, penyajian data, penarikan kesimpulan, dan triangulasi. Dari hasil penelitian menunjukkan bahwa oleh CV. Tunas Abadi Malang menerapkan bauran promosi berupa periklanan, personal selling, hubungan masyarakat, promosi penjualan dan pemasaran langsung. Adapun implikasi implementasi bauran promosi tidak semua kombinasi memiliki dampak besar bagi perusahaan. Selain itu, CV Tunas Abadi melakukan strategi untuk meningkatkan efektifitas penerapan bauran promosi.

Kata kunci: Bauran Promosi, Pendapatan Perusahaan 


\section{Pendahuluan}

Indonesia merupakan negara dengan jumlah penduduk terbesar ke empat di dunia dengan jumlah penduduk 265 juta jiwa berdasarkan data yang dikutip dari okezone.com sehingga menjadikan indonesia sebagai pasar yang potensial, menyebabkan hadirnya banyak industri dengan beragam bidang untuk saling bersaing di dunia usaha. Berbagai strategi pemasaran dilakukan oleh suatu perusahaan agar dapat mampu bersaing dan bertahan di dunia usaha (Fahmi, 2015). Strategi pemasaran sangat penting bagi suatu perusahaan, McCarthy (1996 : 39) menjelaskan bahwa penekanan sisi perencanaan dari pekerjaan manajer pemasaran mengandung alasan penting. Empat komponen seperti yang telah disebutkan oleh McCarthy (1996: 34-36) yaitu produk, tempat, promosi, dan harga. Sebagai bauran pemasaran yang penting bagi perusahaan.

Promosi merupakan komponen penting yang harus diperhatikan oleh suatu perusahaan sebab promosi berkaitan langsung dengan konsumen, karena aktivitas ini bertujuan untuk mempengaruhi konsumen agar membeli produk perusahaan (Fahmi, 2015). Promosi memiliki kombinasi-kombinasi di dalamnya yang digunakan sebagai alat dalam melakukan promosi, Kombinasi ini disebut dengan bauran promosi. Menentukan kombinasi promosi ini cukup sulit bagi perusahaan karena tidak diketahui secara pasti luasnya masing-masing kombinasi promosi tersebut. Sehingga perusahaan harus mengetahui faktor-faktor yang mempengaruhi dalam penentuan kombinasi-kombinasi yang terbaik dari bauran promosi. Adapun pertimbangan yang dijadikan sebagai dasar memilih alat perusahaan antara lain; Jumlah dana yang dipergunakan sebagai promosi, sifat pasar, jenis produk, dan tahap dalam Products life cycle (Swastha, 1986: 240). Sehingga promosi yang dilakukan perusahaan mampu meningkatkan kinerja perusahaan khususnya dalam peningkatan pendapatan perusahaan.

Selain itu, kemajuan zaman semakin modern di mana pengguanaan teknologi dan internet telah menjangkau ke dalam berbagai bidang, termasuk aktivitas berbelanja. Asosiasi Penyelenggara Jasa Internet Indonesia (APJII) menjelaskan hasil survey pada 2017 bahwa sebesar 32,19 persen dari total pengguna internet dipergunakan untuk melakukan pembelian barang. sehingga kemajuan teknologi ataupun internet bisa difungsikan sebagai media promosi yang mudah dan menjangkau lingkup yang luas. Perusahaan dapat menggunakan satu alat promosi atau lebih dalam mengoptimalkan promosi perusahaan. CV. Tunas Abadi Malang adalah salah satu berkegiatan dalam penjualan peralatan kantor, komputer bahkan peralatan sekolah serta menjadi perusahaan jasa yang menyediakan layanan reparasi peralatan elektronik dan non elektronik, baik produk yang dijual perusahaan ataupun produk dari luar perusahaan.

CV. Tunas Abadi telah berdiri sejak tahun 1992 dan telah menghadapi persaingan bisnis di era yang modern dengan pesaing yang semakin banyak. Perusahaan ini menerapkan alat promosi yang cukup konsisten dan lebih memilih memperkuat alat promosi yang dipakai sejak awal berdiri dibanding mengganti alat promosi tersebut, kendatipun jaman mulai bergeser ke arah yang serba digital seperti saat ini. Meskipun CV. Tunas Abadi konsisten dengan alat promosi yang dipakai, ia mampu bertahan dalam persaingan bisnis bahkan telah mendirikan cabang di luar Malang, seperti Jember, Denpasar, Jogyakarta, dan daerah-daerah lainnya.

Dalam personal selling, CV. Tunas Tunas Abadi Malang melakukan penjadwalan bagi tenaga penjualan melalui pengumpulkan data dari instansi atau dinas pemerintah. Cara ini dilakukan dengan melakukan kegiatan sosialisasi dan meminta data para peserta dari berbagai instansi untuk dilakukan follow up selanjutnya. Setiap tenaga penjualan diharuskan 
melakukan kunjungan pada nama-nama dari list daftar hadir tersebut yang diarahkan oleh manajer sesuai wilayah seperti wilayah kota batu, kota malang, dan Kabupaten Malang. Selalin itu, kunjungan ke berbagai instansi juga dilakukan melaui pengambilan data di $e$ catalog yang berisi data tentang instansi-instansi yang membutuhkan barang bagi lembaganya, kemudian pihak CV. Tunas Abadi akan mengerahkan para tenaga penjualan untuk mendatangi instansi-instansi tersebut dan menawarkan barang kepada mereka. Cara ini terbilang efektif sesuai penjelasan Bapak Wadiman selaku tenaga penjualan bagian distribusi, yang menjelasakan bahwa metode ini efektif dalam mempengaruhi instansi untuk membeli produk dari CV. Tunas Abadi bukan dari perusahaan lain. Dalam menggerakkan para tenaga penjualan, dilakukan secara cepat dan serentak di mana setiap tenaga penjualan telah dipersiapkan daftar instansi-instansi yang membutuhkan barang sebelumnya. Sehingga lebih mudah dalam melakukan penjualan.

Berdasarkan latar belakang di atas, maka dapat ditentukan rumusan masalah dari penelitian ini sebagai berikut; 1) Bagaimana implementasi bauran promosi dalam upaya meningkatkan pendapatan perusahaan di CV. Tunas Abadi Kota Malang, 2) Bagaimana implikasi dari implementasi dalam upaya meningkatkan pendapatan perusahaan di CV. Tunas Abadi Kota Malang.

\section{Tinjauan Pustaka}

Buaran Pemasaran

Bauran pemasaran merupakan kegiatan dalam pemasaran yang meliputi empat jenis kegiatan, yaitu kegiatan mengenai produk, promosi, harga, dan distribusi. Dari keempat jenis kegiatan tersebut, perlu dipikirkan strategi yang berkenaan dengan keempat kegiatan tersebut, baik secara individual maupun secara keseluruhan (Rismiati \& Suratno, 2001: 190).

\section{Promosi}

Kinner dan Kenneth dalam setiyaningrum, Udaya, \& Efendi, (2015: 223), mendefinisikan Promosi sebagai sebuah mekanisme komunikasi pemasaran, pertukaran informasi antara pembeli dan penjual. Promosi bertindak untuk menginformasikan, membujuk, dan mengingatkan pelanggan agar menanggapi barang atau jasa yang ditawarkan.

Adapun menururt tjptono (1997: 219) promosi hakikatnya merupakan komunikasi pemasaran yaitu aktifitas pemasaran yang berusaha menyebarkan informasi, mempengaruhi, dan menginatkan pasar sasaran atas perusahaan dan produknya agar bersedia menerima, membeli, dan loyal pada produk yang ditawarkan perusahaan yang bersangkutan.

Sebagaimana penjelasan mengenai pengertian promosi di atas, disimpulkan bahwa tugas utama dalam promosi ada 3 (tiga) yakni sebagai berikut (Setiyaningrum, dkk: 2015: 224):
1) Menginformasikan
Informasi yang bersifat informatif berusaha mengubah kebutuhan yang telah ada menjadi keinginan atau menstimulasi minat pada produk baru.
2) Membujuk 
Pada kondisi ini, konsumen sudah memiliki kesadaran dan pengetahuan akan produk dan cara memenuhi keinginannya. Selain itu, berita promosi juga menekankan pada keunggulan sebenarnya atau yang dipersepsikan mengenai produk tersebut.

\section{3) Mengingatkan}

Promosi juga bertugas untuk mempertahankan merek dalam benak konsumen. Di mana target pasar telah diyakinkan mengenai kebaikan produk yang ditawarkan. Tujuannya untuk mengingatkan kembali produk dalam pasar.

\section{Bauran Promosi}

Kotler (1997: 205) dalam bukunya menyebut istilah bauran promosi dengan bauran komunikasi pemasaran yang terdiri dari lima komponen utama yaitu, periklanan, promosi penjualan, hubungan masyrakat dan publisitas, penjualan pribadi, dan pemasaran langsung.

Bauran promosi adalah perpaduan antara empat unsur promosi yang meliputi iklan, penjualan pribadi, promosi penjualan, hubungan masyarakat, dan publikasi. Promosi yang efektif membutuhkan segmentasi pasar, memberi merek, diferensisiasi produk, dan transaksi penjualan. Oleh sebab itu, memtuskan bauran promosi yang efektif menyangkut pengambilan Keputusan yang strategis. (setiyaningrum, dkk, 2015: 232).

Menurut Rismiati \& Suratno (2001: 255) mendifisikan promotional mix (bauran promosi) merupakan kombinasi strategi yang paling baik dari variabel-variabel perikalanan, personal selling, promosi penjualan, dan alat-alat promosi lain yang bertujuan untuk mencapai program pemasaran.

Tjiptono (1997: 222) mengemukakan bahwa secara umum bentuk-bentuk promosi memiliki fungsi yang sama, tetapi bentuk-bentuk tersebut berdasarkan tugas-tugas khusunya. bauran promosi terdiri dari personal selling, mass selling, promosi penjualan, hubungan masyarakat, pemasaran langsung.

Selain itu, Swastha (1984: 238) dalam bukunya menjelaskan bauran promosi adalah kombinasi strategi yang terdiri dari variabel-variabel perikalanan, personal selling, hubungan masyarakat dan publisitas, serta promosi penjualan.

Pendapat terakhir, Menurut McCarthy dan Perreault (1996: 294) menyebutkan bauran promosi terdiri metode penjualan perseorangan, penjualan massal, dan promosi penjualan.

\section{Komponen Bauran Promosi}

Dari definisi bauran promosi oleh para ahli di atas, dapat disimpulkan bahwa bauran promosi terdiri dari beberapa komponen sebagai berikut :

a. Periklanan

Setiyaningrum., dkk (2015: 233) menjelaskan periklanan sebagai bentuk presentasi non-personal dan promosi atas gagasan dan produk oleh seseorang yang memanfaatkan media, seperti majalah, poster, radio, katalog, sirkuler, dan televisi. Kotler (1997: 205) Adalah semua bentuk penyajian non-persoal dan promosi ide, barang atau jasa yang dibayar oleh suatu sponsor tertentu.

b. Personal Selling 
Swastha (1984: 238-284) Adalah Interaksi antar individu, saling bertemu muka yang ditujukan untuk menciptakan, memperbaiki, menguasai, atau mempertahankan hubungan pertukaran yang saling menguntungkan dengan pihak lain.

Menurut McCarthy (1996: 314) personal selling merupakan aktifitas yang Melibatkan pembicaraan langsung antara penjualan dan pelanggan potensial. Penjualan tatap muka ini menyediakakn umpan balik segera yang membantu wiraniaga untuk menyesuaikan diri.

c. Promosi Penjualan

Tjiptono (1997: 222) menjelaskan promosi penjualan merupakan bentuk persuasi langsung melalui penggunaan berbagai insentif yang dapat diautr untuk merangsag pembelian produk dengan segera atau meningkatnkan jumlah barang yang dibeli pelanggan.

Sedangka menurut Rismiati \& Suratno (2001: 255) Promosi penjualan merupakan kegiatan pemasaran selain periklanan, personal selling, dan publisitas yang mendorong pembelian barang oleh pembeli. Kegiatan promosi penjualan di antaranya pameran, peragaan, demonstrasi, dan sebaginya.

d. Hubungan masyarakat

Setiyaningrum., dkk, menjelaskan (2015: 233) Bentuk promosi ini dapat membantu perusahaan untuk berkomunikasi baik dengan konsumen, pemasok, investor, pejabat pemerintah, karyawan, dan masyarakat. Hubungan masyarakat menyampaikan kesan positif mengenai perusahaan, serta mendidik mereka untuk tujuan dan sasaran perusahaan bahkan memperkenalkan produk baru dan mendukung usaha penjualan produk.

Kotler (1997: 205) dengan menggunakan surat, telepon, faksimil, e-mail, dan alat penghubung non-personal lain untuk berkomunikasi secara langsung dengan atau mendapatkan tanggapan langsung dari pelanggan tertentu dan calon pembeli.

e. Publisitas

Rismiati \& Suratno (2001: 255) mendefinisikan Publisitas merupakan pemberitaan secara komersial di media massa atau sponsor secara non-pribadi dengan tujuan untuk mendorong permintaan atas produk, jasa, atau ide perusahaan. Publisitas membrikan peran yang sangat besar bagi seluruh program promosi.

Adapun Swastha menjelaskan (1984 : 238-284) publisitas adalah sejumlah informasi tentang sesorang, barang, atau organisasi yang disebarluaskan kepada masyarakat melalui media tanpa dipungut biaya, atau tanpa pengawasan dari sponsor.

f. Pemasaran Langsung

Tjiptono (1997: 222) mendifinisikan pemasaran langsung adalah sistem pemasaran yang berifat interaktif, yang memanfatkan satu atau beberapa iklan untuk menimbulkan respon yang terukur dan transaksi di sembarang lokasi. Dalam pemasaran langsung, komunikasi promosi ditujukan langsung kepada konsumen invidual, dengan tujuan agar pesan tersebut ditanggapi konsumen yang bersangkutan, baik melalui telepon, pos, atau datang langsung ke tempat pemasar. 
Kotler (1997: 205) Dengan menggunakan surat, telepon, faksimil, e-mail, dan alat penghubung non-personal lain untuk berkomunikasi secara langsung dengan atau mendapatkan tanggapan langsung dari pelanggan tertentu dan calon pembeli.

\section{Tinjauan Penelitian Terdahulu}

Penelitian oleh Ni Putu Winda, dkk (2015) dengan judul penelitian "Analisis Bauran Promosi Kopi Luwak di UD Cipta Lestari Desa Pujungan Kecamatan Pupuan Kabupaten Tabanan" pada penelitian ini, UD. Cipta Lestari menerapkan bauran promosi berupa periklanan, Penjualan Perseorangan, Promosi penjualan, Hubungan Masyarakat, dan pemasaran langsung. Sedangkan kendala yang dihadapi adalah kurangnya biaya untuk periklanan, kurangnya reaksi masyarakat terhadap seminar yang sering dilaksanakan oleh UD. Cipta Lestari dan kurangnya akses internet dan lemahnya jaringan operator cellular serta kurangnya biaya untuk mengikuti pameran dagang. Adapun persamaan penelitian ini adalah sama-sama membahasa implementasu bauran promosi. Akan tetapi dengan objek dan fokus penelitian yang berbeda.

\section{Metodologi Penelitian Desain Penelitian}

Penelitian ini dilakukan di CV. Tunas Abadi Malang. Jenis Penelitian ini adalah penelitian deskriptif kualitatif dengan melakukan wawancara langsung, pengamatan dan studi kepustkaan. Metode ini digunakan untuk mencari suatu uraian yang menyeluruh dan teliti dari sutau keadaan berdasarkan hasil wawancara bersama para informan yang ditetapkan.

\section{Subjek Penelitian}

Dalam penelitian ini pengambilan sampel dilakukan melalui teknik purposive sampling, yaitu pengambilan sampel dengan adanya pertimbangan tertentu. Di mana sampel adalah informan yang merupakan orang-orang yang dianggap mengetahui tentang implementasi bauran promosi di CV Tunas Abadi Malang. Adapun informan dalam penelitian ini diantaranya Bapak Moch. Tumiran Dhair (Direktur Utama), Bapak Roles May Sugiarto., S.E (Tenaga penjualan divisi presentasi), Bapak Wadiman (Tenaga Penjualan bagian distribusi), dan bapak Yakub Fauzan (Konsumen).

\section{Metode Pengumpulan Data}

Dalam Penelitian ini digunakan tiga jenis instrumen pengumpulan data, yakni wawancara, pengamatan, dan studi kepustakaan. Wawancara dilakukan secara langsung dan tak terstruktur. Pengamatan dilakukan terhadap implementasi bauran promosi di CV. Tunas Abadi Kota Malang. Sedangkan studi kepustakaan, dipakai untuk mengumpulkan data melalui dokumen dan laporan lainnya yang dapat dianggap mendukung serta melengkapi hasil penelitian.

\section{Teknik Analisis Data}

Miles dan Huberman yang dikutip dari Sugiyono ( 2016: 245) mengemukakan bahwa aktivitas dalam analisis data kualitatif dilakukan secara interaktif dan berlangsung secara terus menerus sampai tuntas, sehingga datanya sudah jenuh. Adapun proses meliputi reduksi data ; bertujuan untuk memfokuskan data dari lapangan 
pada bahasan yang diperlukan dalam penelitian. Penyajian data, data dapat disajikan dalam bentuk diagram dan narasi yang mudah dipahami. Terakhir, kesimpulan/verifikasi yaitu dengan dilakukan penarikan kesimpulan, maka tugas peneliti untuk memverifikasi penyajian data dengan didukung oleh data-data yang valid dan konsisten sehingga dapat digunakan sebagai kesimpulan yang kredibel.

\section{Hasil dan Pembahasan}

A. Implementasi Bauran Promosi Pada CV Tunas Abadi Malang

Berdasarkan hasil dari wawancara dan observasi yang peneliti telah dilakukan ditemukan bahwa bauran promosi yang diterapkan oleh CV. Tunas Abadi Malang menggunakan lebih dari 1 alat promosi agar mampu menarik segmentasi pasar dan bersaing dengan perusahaan sejenis lainnya. CV. Tunas Abadi Malang menggunakan beberapa bauran promosi, diantaranya adalah periklanan, personal selling (penjualan perorangan), promosi penjualan, hubungan masyarakat, dan pemasaran langsung. Berikut penjelasan masing-masing implementasi bauran promosi pada CV. Tunas Abadi Malang:

1) Periklanan

Adapun media periklanan yang digunakan di CV. Tunas Abadi untuk melakukan promosi antara lain:

a) Internet

CV. Tunas Abadi juga salah satu perusahaan yang memanfaatkan internet untuk periklanan sejak akhir 2017. Hal ini disebabkan keikutsertaan CV Tunas Abadi menjadi salah satu penyedia barang di catalog.id yang merupakan website resmi pemerintah yang digunakan untuk penjualan barang pada instansi pemerintah.

b) Media Massa

CV. Tunas Abadi menjadikan media massa sebagai salah satu media periklanan yang dapat dilihat oleh masyarakat umum. Media massa yang digunakan oleh CV. Tunas Abadi tersebut adalah videotron. Videotron adalah bentuk reklame yang berupa visual bergerak dengan kelebihan mampu menampilkan gambar bergerak yang membuat materi iklan terlihat menarik serta dapat menyesuaikan keinginan.

c) Media Cetak

CV. Tunas Abadi memanfaatkan koran dan brosur sebagai media periklanannya dengan tujuan memperluas akses bagi masyarakat untuk mengatahui informasi produk dan program yang sedang dilakukan oleh perusahaan.

Maka dari itu, terkadang CV. Tunas Abadi memanfaatkan media cetak berupa koran yang dimuat di koran-koran lokal atas kerjasama antara CV. Tunas Abadi dan penerbit (Radar Malang dan Radar Pos).

Penerapan periklanan pada CV. Tunas Abadi Kota Malang selaras dengan penjelasan Setiyaningrum., dkk, (2015 : 233) bahwa periklanan adalah bentuk presentasi non-personal dan promosi atas gagasan serta produk oleh seseorang yang memanfaatkan media, seperti majalah, poster, radio, katalog, sirkuler, dan televisi. 
2) Personal Selling

Dari hasil wawancara-wancara dan observasi yang telah dilakukan, menunjukkan bahwasanya secara teknis penerapan personal selling pada $\mathrm{CV}$. Tunas Abadi sangat baik berdasarkan penuturan dari para informan. Para tenaga penjulan dibekali dengan product knowledge yang baik sebagai bahan presentasi kepada para konsumen.

Penerapan personal selling ini pada CV. Tunas Abadi Malang selaras dengan pernyataan Tjiptono (1997: 222) mengenai konsep personal selling yang merupakan komunikasi langsung (tatap muka) antara penjual dan pembeli dan calon pelanggan untuk memperkenalkan suatu produk kepada calon pelanggan dan membentuk pemahaman pelanggan terhadap produk sehingga mereka akan mencoba dan membelinya.

3) Hubungan Masyarakat

Dari hasil wawancara mengenai hubungan masyarakat dapat simpulkan bahwa CV. Tunas Abadi menerapkan hubungan masyarakat dalam bentuk ; a) Sumbangan pada lembaga sosial seperti panti asuhan dan panti jompo dan acara masyarakat sekitar kantor. b) Menerima bantuan melalui pengajuan bantuan proposal kegiatan. c) Mendukung kegiatan shalawatan dan yasinan masyarakat umum. d) Mengundang kelompok-kelompok tertentu untuk berbuka bersama dan santunan pada saat bulan ramadlan.

Kegiatan-kegiatan yang dilakukan oleh tunas abadi dalam menerapkan hubungan masyarakat bertujuan untuk menjalin hubungan yang baik dan membangun citra baik perusahaan dalam masyarakat. Hal ini sesuai dengan konsep hubungan masyarakat oleh Kotler (1997: 205) yang menyatakan bahwa berbagai program untuk mempromosikan dan melindungi citra perusahaan atau produk individualnya adalah tujuan dari hubungan masyarakat.

4) Promosi Penjualan

CV. Tunas Abadi telah menerapkan harga terbaik pada setiap pelanggannya. Di samping itu, CV. Tunas Abadi juga menggunakan potongan harga (diskon) pada beberapa jenis barang yang telah menumpuk di gudang sehingga perlu dijual dengan segera, maka dari itu cara yang dilakukan adalah dengan pemberlakuan diskon. Berdasarkan dari observasi, peneliti ditemukan bahwa CV Tunas Abadi juga menggunkan undian berhadiah (doorpize) pada acara-acara yang diselenggarakan oleh CV. Tunas Abadi seperti pada sosialisasi takmir se-Malang Raya.

Dari hasil wawancara kepada 3 informan dan observasi, ditemukan bahwa CV. Tunas Abadi Malang menerapkan promosi penjualan dalam bentuk; a) pemberian "harga terbaik", b) potongan harga atas barang tertentu yang telah menumpuk di gudang, dan c) pemberian undian berhadiah dalam acara-acara yang diadakan oleh CV. Tunas Abadi. Kegiatan promosi penjualan tersebut sesuai dengan penjelasan Swastha (1984: 238284) mengenai metode-metode promosi penjualan konsumen yang dapat digunakan dalam promosi penjualan meliputi : Pemberian contoh barang (sampel), Kupon/nota, Hadiah,Kupon berhadiah, Undian, Rabat (cash refund), Peragaan. 
5) Pemasaran Langsung

Berdasarkan keterangan hasil dari wawancara dan observasi disimpulkan bahwa CV. Tunas Abadi menerapkan 4 bentuk pemasaran langsung yaitu kiosk marketing, telemarketing, katalog, dan direct mail.

a) Kiosk marketing/pemasaran toko

CV. Tunas Abadi menyediakan toko yang berada dalam satu bangunan dengan kantor. Di dalam Toko dipajang sampel produk perusahaan. Dalam hal operasional toko, CV. Tunas Abadi memanfaatkan Showroom yang bertugas menjaga toko dan melayanai setiap calon pembeli yang datang.

b) Telemarketing

CV. Tunas Abadi menggunakan telemarketing untuk memberikan informasi langsung terkait adanya produk baru, harga dan promosi yang sedang dilakukan CV. Tunas Abadi Malang. Telemarketing menjadi tanggung jawab pihak showroom/front office untuk menghubungi para konsumen serta menanggapi segala pertanyaan dan keluhan para konsumen.

c) Direct Mail

Direct mail masih cukup efektif diterapkan sebagai salah satu alat promosi dalam pemasaran langsung. Pemasaran melalui email pada CV Tunas Abadi Malang biasanya dilakukan oleh para konsumen yang berada di luar Malang. Sehingga mempermudah proses pembelian tanpa harus bertemu langsung antara penjual dan pembeli.

d) Katalog

Katalog merupakan buku yang menyajikan daftar deskripsi produk, harga dan data-data lain yang terkait. CV. Tunas Abadi mencetak katalog sesuai dengan divisi produk perusahaan agar mempermudah untuk menemukan produk yang diinginkan oleh konsumen.

Hal yang dilakukan oleh CV. Tunas Abadi Malang terkait pemasaran langsung sesuai dengan penjelasan Kotler (1997: 205) yang menyebutkan bahwa pemasaran langsung menggunakan surat, telepon, faksimil, e-mail, dan alat penghubung non-personal lain untuk berkomunikasi secara langsung dengan atau mendapatkan tanggapan langsung dari pelanggan tertentu dan calon pembeli.

6) Publisitas

Publisitas dapat melakukan peran yang tidak dapat dilakukan oleh periklanan, yakni mampu memuat informasi yang cukup panjang dan minim biaya bahkan tidak berbayar. Akan tetapi, CV. Tunas Abadi tidak memanfaatkan publisitas sebagai salah satu bauran promosi. Hal ini disebabkan publisitas tidak memberi dampak pada CV. Tunas Abadi Malang.

B. Implikasi Implementasi Bauran Promosi Pada CV. Tunas Abadi Kota Malang

1) Periklanan

Berdasarkan hasil wawancara di atas dapat ketahui bahwa penerapan periklanan memberikan dampak positif bagi CV Tunas Abadi. Adapun dampak tersebut antara lain ; a) Mendorong peningkatan penjualan, 2) Meningkatkan pengetahuan masyarakat. 
2) Personal Selling

Dari ketiga hasil wawancara bersama para informan dapat diketahui bahwa dampak penerapan personal selling bagi CV. Tunas Abadi adalah meningkatnya volume penjualan karena mampu menarik konsumen untuk melakukan pembelian produk perusahaan. Hal ini dilakukan melalui pendekatan, kunjungan dan komunikasi yang baik dari para tenaga penjualan kepada para calon pembeli dan pelanggan.

3) Hubungan Masyarakat

Melalui hasil wawancara-wawancara yang telah peneliti lakukan, dapat diketahui bahwa dampak dari penerapan hubungan masyarakat bagi CV. Tunas Abadi Malang meliputi ; a) Perusahaan akan semakin dikenal oleh masyarakat, b) Adanya repeat order dari pengaju sponsorship, c) Memungkinkan penyebarluasan informasi perusahaan melalui lembaga yang diberi bantuan.

4) Promosi Penjualan

Berdasarkan pada hasil wawancara pada para informan diketahui bahwa CV. Tunas Abadi Malang menerapkan promosi penjualan memiliki dampak tersendiri bagi perusahaan. Implikasi dari implementasi promosi penjualan pada CV. Tunas Abadi Malang adalah a) Mampu menciptakan kepuasan pelanggan melalui pemberian harga terbaik, b) Meningkatkan volume penjualan perusahaan.

5) Pemasaran Langsung

Dampak yang diperoleh oleh CV. Tunas Abadi Malang dari penerapan pemasaran langsung cukup efektif tetapi masih relatif lebih kecil dibandingkan dengan hasil yang diperoleh dari personal selling. Sehingga dapat diperinci berdasarkan penjelasn para informan bahwa implikasi dari penerapan pemasaran langsung pada CV Tunas Abadi terdiri dari : a) Mencapai kepuasan pelanggan, b) Memberikan kemudahan dalam melakukan komunikasi.

\section{Kesimpulan}

Dari pembahasan mengenai implementasi baurna promosi pada CV. Tunas Abadi Malang, maka dapat ditarik kesimpulan bahwa CV. Tunas Abadi Malang menerapkan lima kombinasi dari bauran promosi, yaitu periklanan, personal selling, promosi penjualan, hubungan masyarakat, dan pemasaran langsung.

Implikasi dari implementasi kombinasi-kombinasi bauran promosi yang dilakukan oleh CV. Tunas Abadi malang meliputi; mendorong peningkatan penjualan dan meningkatkan pengetahuan masyarakat pada CV. Tunas Abadi, adanya repeat order, penyebarluasan informasi perusahaan melalui lembaga yang diberi bantuan, mampu menciptakan kepuasan pelanggan melalui pemberian harga terbaik, dan memberikan kemudahan dalam melakukan komunikasi.

Pada dasarnya, CV Tunas Abadi Malang melakukan strategi pada semua kombinasi bauran promosi yang diterapkan. Akan tetapi, CV Tunas Abadi Malang lebih memperhatikan personal selling, karena menjadi alat promosi utama perusahaan yang memiliki dampak besar bagi perusahaan. Adapun periklanan, promosi penjualan, dan hubungan masyrakat, dan pemasaran langsung berfungsi sebagai alat pendukung dan melengkapi promosi lainnya. 


\section{Saran}

Terdapat beberapa saran yang akan peneliti berikan sebagai sumbangsih pemikiran dan bahan masukan bagi CV. Tunas Abadi Malang, sebagai berikut :

1) CV. Tunas Abadi harus semakin gencar dalam menyebarkan informasi tentang promosi penjualan. Karena masih banyak konsumen yang tidak mengetahui informasi promosi penjualan bahkan banyak dari konsumen yang menanyakan promosi ketika sudah di luar waktu berlakunya program promosi.

2) CV. Tunas Abadi Malang mengganggap publistias tidak berdampak pada perusahaan, namun informasi perusahan perlu dipublikasikan terutama di media online seperti website atau blog.

3) Dalam personal selling, tenaga penjualan harus terus mencari konsumen baru agar kuantitas pembeli dan penjualan meningkat. Hal ini dikarenakan banyak dari para tenaga penjualan mengandalkan para pelanggan lama yang dianggap lebih potensial dibanding pembeli baru.

\section{DAFTAR PUSTAKA}

Apjii.or.id diakses pada 15 Februari 201921.30 WIB

Dewi, Ni Putu Winda Purnami, dkk. 2015. Analisis Bauran Promosi Kopi Luwak di UD Cipta Lestari Desa Pujungan Kecamatan Pupuan Kabupaten Tabanan. E-Jurnal Agribisnis dan Agrowisata hlm. 298-306

Economy.okezone.com diakses pada 14 Februari 201920.54 WIB

Fahmi, S. 2015. Analisis Perencanaan Strategi Pemasaran Pada PT. Hapeel Pharmindo, Jurnal Manajemen Bisnis Indonesia, vol.2 No.3, https://doi.org/10.31843/jmbi.v2i3.59.

Kottler, P. (1997). Manajemen Pemasaran. Jakarta: PT Prenhallindo.

McCarthy, E. Jerome., \& William D. Perrault, JR. (1996). Dasar-Dasar Marketing. Jakarta: ERLANGGA.

Sugiyono. (2016). Metode Penelitian Kuantitatif, Kualitatif, dan R\&D. Bandung: Alfabeta.

Swastha, B. (1984). Azas-Azas Marketing. Yogyakarta: Liberty, Yogyakarta.

Tjiptono, F. (1997). Strategi Pemasaran. Yogyakarta: ANDI. 